\title{
Pengetahuan Santri Mengenai Wawasan Kebangsaan Dalam Implementasi Aspek Kehidupan Sosial Di Pesantren
}

\author{
Oleh.: \\ Muhammad Aji Rajab Saputra \\ Email: adjie.rajab@gmail.com \\ Progam Studi Magister Pendidikan IPS \\ Pascasarjana Universitas Lambung Mangkurat Banjarmasin
}

\begin{abstract}
Abstrak
Artikel ini bertujuan untuk menjabarkan mengenai pengetahuan dan pemahaman para santri di pesantren mengenai wawasan kebangsaan baik itu dari pengertian, konsep maupun implementasinya pada kehidupan sosial bermasayarakat di sekitar lingkungan Pesantren Intan Ilmu. Pentingnya santri di Pesantren Intan Ilmu dalam memahami arti dari wawasan kebangsaan adalah sebagai bentuk kontrol terhadap ilmu agama yang didapatkan di pesantren agar dipergunakan untuk membangun masa depan bangsa yang religius namun tetap cinta terhadap tanah airnya. Jenis penelitian dalam artikel ini adalah penelitian deskriptif kualitatif dimana data yang didapat secara langsung dari santri di Pesantren Intan Ilmu dimana jumlah informan sebanyak 6 santri. Teknik pengumpulan data dengan menggunakan observasi, wawancara dan dokumentasi. Kemudian menggunakan analisis data berupa pengumpulan data, penyajian data dan penarikan kesimpulan. Hasil penelitian dalam artikel ini yaitu bahwasanya pengetahuan santri mengenai wawasan kebangsaan meliputi 3 (tiga) hal yaitu, pemikiran atau perspektif dari santri terkait wawasan kebangsaan, cara santri dalam mengimplementasikan wawasan kebangsaan dan terakhir adalah kendala dalam mengimplementasikan wawasan kebangsaan.
\end{abstract}

Kata Kunci: Wawasan Kebangsaan, Aspek Sosial dan Pesantren Intan Ilmu.

\section{A. PENDAHULUAN}

Wawasan kebangsaan merupakan sebuah pemahaman mengenai suatu objek yang mempengaruhi dirinya dalam rangka untuk menumbuhkan dan memiliki rasa cinta terhadap tanah air bangsa dan negara yang mana pemahaman ini telah diciptakan dalam rangka bagian penting dari sebuah konstruksi elit politik terhadap bangsa Indonesia.Wawasan kebangsaan menentukan cara bangsa dengan cara mendayagunakan segala kondisi geografis negara, sejarah, sosial-budaya, ekonomi dan politik serta pertahanan keamanan dalam mencapai cita-cita dan menjaga kepentingan nasional bangsa. Wawasan kebangsaan merupakan suat hal yang penting untuk dimiliki oleh bangsa Indonesia karena hal itu merupakan sebuah asset yang berharga yang bertujuan untuk menumbuhkan kesadaran pengakuan bangsa sebagai makhluk ciptaan Allah Subhanahu Wata'ala, tekad untuk hidup sebagai bangsa yang merdeka, bebas dan bersatu, 
mencintai tanah air dan negara, demokrasi, kesetiakawanan sosial adil dan makmur. Nilai-nilai ini sangat perlu diterapkan dan diimplementasikan dalam kehidupan bangsa dan negara agar nantinya setiap tindakan aksi yang dilakukan oleh warga negara tersebut akan menimbulkan suatu hal yang positif sebagai alat pemersatu bangsa dan berfungsi juga sebagai benteng pertahanan negara dari luar.

Wawasan kebangsaan sering disebut juga wawasan nusantara, dimana konsep itu merupakan sebuah pandangan bangsa Indonesia yang timbul dikarenakan adanya kesadaran individu serta dari hasil sejarah panjang yang menempa mereka yang didalamnya mengandung nilai luhur bangsa. Nilai-nilai itu antara lain seperti rela berkorban demi kepentingan bangsa dan negara, bersatu dalam perjuangan menggapai cita-cita, kekeluargaan dalam menjalin hubungan yang harmonis antar individu dengan kelompok, serta gotong royong untuk saling peduli ikhlas dalam tolong menolong memenuhi kebutuhan.

Menurut Fauzi (2017) menyatakan bahwasanya wawasan kebangsaan merupakan sebuah cara pandang dimana hal itu berlandaskan dengan sebuah rasa sadar diri sebagai individu dari sebuah negara mengenai diri dan lingkungan masyarakat dalam kehidupan bangsa dan negara. Prof. Muladi, Gubernur Lemhannas RI juga memaparkan bahwasanya wawasan kebangsaan sebagai pandangan bangsa Indonesia terhadap individu dan lingkungannya dengan tetap mengutamakan segala persatuan wilayah dalam setiap penyelanggaraan kehidupan masyarakat, bangsa dan negara. Kesatuan nasional tersebut bukan hanya bersifat terstruktur, namun bersifat kultural yang mengandung satu kesatuan ideologi, politik, sosial budaya, ekonomi serta pertahanan dan keamanan. Yang mana hal tersebut dapat menentukan bangsa tersebut untuk bisa menempatkan diri dalam tata cara berhubungan dengan bangsa lain dalam pergaulan international.

Wawasan kebangsaan mengandung sebuah komitmen tegas dan semangat persatuan di dalamnya yang berfungsi untuk menjamin setiap keberadaan serta peningkatan kualitas hidup bangsa dan negara serta menghendaki pengetahuan yang mumpuni mengenai tantangan bangsa bai itu di masa sekarang maupun masa depan. Selain itu juga wawasan kebangsaan menentukan cara bangsa dalam mendayagunakan kondisi setiap aspek bernegaranya seperti kondisi geografis negara, sejarah, sosial budaya, ekonomi, politik serta pertahanan dan kemanan dalam membangun dan mewujudkan cita-cita serta menjamin kepentingan nasional. 
Pemuda merupakan salah satu asset bangsa dan merupakan generasi potensial dalam pergerakan kemajuan suatu bangsa. Sikap kritis pemuda sangatlah digunakan untuk menjadi bagian dari pergerakan kemajuan bangsa dan negara. Selain itu juga mereka memiliki peran penting karena dinilai dari kemampuan, semangat dan pengetahuan yang lebih unggul dibandingkan masyarakat pada umumnya, apalagi jika mereka dibekali dengan ilmu agama serta memiliki akhlak dan budi pekerti yang bagus. Tentunya hal ini akan menimbulkan sebuah perubahan yang besar dalam mewujudkan tujuan bangsa dan negara. Salah satu bagian dari pemuda tersebut adalah santri. Sejarah telah mencatat begitu banyaknya peran santri dalam pembangunan peradaban di Indonesia. Para pemuda yang merupakan santri tersebut, menempuh pendidikan dalam sebuah wadah pendidikan yang dinamakan pesantren.

Pesantren merupakan sebuah pendidikan yang cukup tua berkembang di Indonesia terutama di pulau Jawa sejak abad ke-17. Kehadirannya dalam rentetan peristiwa sejarah Indonesia telah banyak memberikan hipotesis yang mungkin telah teruji, dimana dalam melawan berbagai bentuk perubahan sosial di masyarakat, pesantren digunakan sebagai wadah dan tempat penyebaran dan sosialisasi menyebarnya agama Islam. Pesantren juga ikut andil dalam berbagai upaya untuk meningkatkan taraf hidup warga. Bukan hanya dari segi akhlak, tetapi juga berperan memberikan sumbangsih yang signifikan dalam pendidikan di negara kita Indonesia. Sebagai tempat pengajaran ilmu agama Islam, pesantren juga sudah banyak melahirkan para ulama, kyai, para tokoh masyarakat, bahkan guru-guru agama yang sampai saat ini sangat dibutuhkan oleh masyarakat. Sampai saat ini, pesantren selalu konsisten menyelenggarakan berbagai fungsi dan tujuannya dengan baik, bahkan sebagian kini telah mengembangkan fungsi dan perannya sebagai wadah penyelenggaraan pendidikan di tengah kehidupan masyarakat.

Pesantren merupakan sebuah dunia pendidikan yang menarik untuk dikaji dan iteliti. Meskipun selama ini banyak penelitian yang menjadikan pesantren sebagai objek kajian, dan hal itu selalu menunjukkan persepektif tertentu yang belum bisa terungkap. Itu menandakan bahwasanya pesantren memiliki ciri khas dan kekayaan khazanah pengetahuan sosial tersendiri yang dapat dikaji dari berbagai persfektif ilmu pengetahuan. Posisi pesantren yang demikian tersebut menandakan bahwa pesantren bukan hanya lembaga pendidikan Islam tertua di Indonesia yang masih eksis sampai saat ini, namun juga merupakan sebuah entitas sosial yang mempunyai pengaruh kuat sekaligus unik dalam membangun karakter bangsa termasuk diantaranya wawasan kebangsaan berbangsa dan bernegara. 
Dewasa ini pesantren sebagai sebuah entitas pendidikan dan dakwah dihadapkan dengan berbagai tantangan, termasuk di dalamnya pembaharuan pendidikan Islam. Pada banyak hal, sistem dan kelembagaan pesantren telah dilakukan modernisasi dan diperbaharui sesuai dengan tuntutan dan perkembangan zaman. Pesantren saat ini memiliki banyak isu dan persepsi negatif yang berkembang dimasyarakat yang mana salah satunya adalah sebagai wadah paham radikalisme yang dapat merongrong keutuhan bangsa dan negara. Proses transfer ilmu yang diberikan oleh pesantren, seringkali dianggap berlebihan oleh sebagian masyarakat karena terlihat tidak umum atau terlalu mencontoh budaya timur tengah. Padahal jika dilihat dan dikaji lebih dalam, pesantren sebenarnya hanya mengajarkan ilmu berdasarkan syari'at Islam yaitu Alquran dan Sunnah Nabi Muhammad Shallalahu Alaihi Wasallam dengan berdasarkan pemahaman para sahabat radhiyallahu'anhum yaitu generasi terbaik umat Islam. Hal itu tentunya menimbulkan dampak tersendiri bagi masyarakat ketika akan menjalin hubungan timbal balik dengan pesantren.

Proses pendidikan penanaman wawasan kebangsaan terhadap santri di pesantren modern yaitu di Pesantren Intan Ilmu Barito Kuala Kalimantan Selatan bisa dijadikan sebuah kajian penelitian. Penanaman sikap wawasan kebangsaan bukan hanya sebatas teori yang hanya diajarkan dalam mata pelajaran Pendidikan Kewarganegaraan, IPS dan juga Seni Budaya di Pesantren Intan Ilmu, namun juga dengan melaksanakan sebuah praktek langsung di lapangan. Pesantren Intan Ilmu memiliki hubungan yang erat dengan warga desa lok rawa mandastana di sekitarnya. Seringnya acara kegiatan yang bersifat sosial yang dilakukan oleh Pesantren setiap tahunnya seperti Penyaluran Zakat Maal, Penyaluran hewan qurban, sunatan massal, dan kegiatan berbagi sembako di tengah masa pandemi Covid-19. Kegiatan-kegiatan sosial tersebut merupakan wujud kongkret sikap wawasan kebangsaan Pesantren Intan Ilmu dalam membina hubungan yang baik dalam kehidupan bermasyarakat berbangsa dan bernegara. Pentingnya santri di Pesantren Intan Ilmu dalam memahami arti dari wawasan kebangsaan adalah sebagai bentuk kontrol terhadap ilmu agama yang didapatkan di pondok pesantren agar dipergunakan untuk membangun masa depan bangsa yang religius namun tetap cinta terhadap tanah airnya.

\section{B. METODE}

Jenis penelitian dalam artikel ini adalah penelitian deskriptif kualitatif. Penelitian kualitatif dekspriptif merupakan suatu metode yang didasarkan pada filosofi postpositivisme 
yang biasanya digunakan untuk penelitian dalam kondisi yang alamiah, dimana peneliti berperan sebagai istrumen utama (Riyadi, 2018:170). Dalam penelitian ini, penulis melakukan proses penelitian secara langsung dan aktif melalui wawancara dan observasi. Menurut Raco (2018:112) dalam tradisi kualitatif, data tidak diperoleh dibelakang meja, tetapi harus turun ke lapangan, ke tetangga, ke organisasi, ke komunitas. Data yang diobservasi seperti gambaran tentang sikap, perilaku, kelakuan, tindakan dan keseluruhan interaksi antar manusia. Data observasi juga dapat berupa interaksi dalam suatu organisasi ataupun pengalaman para anggota dalam berorganisas. Dalam artikel ini observasi dilakukan dengan mengumpulkan berbagai sumber serta materi yang berkaitan tentang pengetahuan santri mengenai wawasan kebangsaan.

Indikator dari penulisan artikel ini dijabarkan ke dalam kisi-kisi wawancara yang memfokuskan pemahaman dan pengetahuan santri mengenai wawasan kebangsaan yaitu pemahaman santri mengenai wawasan kebangsaan yang mereka pahami, Implementasi wawasan kebangsaan dalam aspek kehidupan dan Kendala yang dihadapi terkait pengimplementasian wawasan kebangsaan dalam kehidupan nyata. Data yang dikumpulkan dalam penelitian ini berupa data primer, yaitu data yang didapat secara langsung dari 6 orang santri di Pesantren Intan Ilmu. Sedangkan data sekunder dalam artikel ini adalah data yang diperoleh dari informasi yang telah diolah dari pihak Pesantren. Penjelasan dan penyajian data, pada artikel penulisan ini yaitu penulis mencari penjelasan yang logis guna menjelaskan keterkaitan diantara hasil data tersebut. Kajian pustaka dan teori-teori yang berkaitan dengan tema wawasan kebangsaan dan implementasi aspek sosialnya bagi santri di Pesantren Intan Ilmu.

Penelitian serupa pernah dilakukan oleh Ahmad Zajuli dan M. Turhan Yani Tahun 2017 dengan judul Konstruksi Santri tentang Wawasan Kebangsaan di Pondok Pesantren Bureng Kecamatan Wonokromo Kota Surabaya. Dimana hasil yang didapatkan bahwasanya cara santri di Pondok Pesantren Bureng Kecamatan Wonokromo dalam mengimplementasikan wawasan kebangsaan menjadikan nilai dan norma yang diperoleh di psantren tersebut sebagai bekal dalam berprilaku setiap harinya. Kemudian perlunya batasan dalam perilaku dan mengerti bahwa Allah Subhanahu Wata'ala Maha Melihat. Selain itu, saran dari penelitian yang dilakukan oleh Ahmad Zajuli dan M. Turhan Yani ini menyarankan agar perlunya pengimplementasian wawasan kebangsaan melalui nilai-nilai Pancasila, Bhineka Tunggal Ika dan penjabaran norma hukum dari UUD 1945. Oleh karena itu dalam penulisan artikel ini, penulis mencoba mengkaji dan meneliti 
mengenai pemahaman santri Pesantren Intan Ilmu mengenai wawasan kebangsaan yang diimplementasikan ke dalam aspek kehidupan sosial sekitar.

\section{HASIL DAN PEMBAHASAN}

\section{Pengertian Wawasan Kebangsaan}

Menurut KBBI dinyatakan bawasanya secara makna wawasan kebangsaan sebagai konsepsi cara pandang yang dilandasi akan kesadaran diri sebagai warga dari suatu negara akan diri dan lingkungannya di dalam kehidupan bangsa dan negara. Menurut Fauzi (2017) menyatakan bahwasanya wawasan kebangsaan merupakan sebuah cara pandang dimana hal itu berlandaskan dengan sebuah rasa sadar diri sebagai individu dari sebuah negara mengenai diri dan lingkungan masyarakat dalam kehidupan bangsa dan negara. Prof. Muladi, Gubernur Lemhannas RI juga memaparkan bahwasanya wawasan kebangsaan sebagai pandangan bangsa Indonesia terhadap individu dan lingkungannya dengan tetap mengutamakan segala persatuan wilayah dalam setiap penyelanggaraan kehidupan masyarakat, bangsa dan negara. Kesatuan nasional tersebut bukan hanya bersifat terstruktur, namun bersifat kultural yang mengandung satu kesatuan ideologi, politik, sosial budaya, ekonomi serta pertahanan dan keamanan. Yang mana hal tersebut dapat menentukan bangsa tersebut untuk bisa menempatkan diri dalam tata cara berhubungan dengan bangsa lain dalam pergaulan international.

Wawasan kebangsaan mengandung sebuah komitmen tegas dan semangat persatuan di dalamnya yang berfungsi untuk menjamin setiap keberadaan serta peningkatan kualitas hidup bangsa dan negara serta menghendaki pengetahuan yang mumpuni mengenai tantangan bangsa bai itu di masa sekarang maupun masa depan. Selain itu juga wawasan kebangsaan menentukan cara bangsa dalam mendayagunakan kondisisetiap aspek bernegaranya seperti kondisi geografis negara, sejarah, sosial budaya, ekonomi, politik serta pertahanan dan kemanan dalam membangun dan mewujudkan cita-cita serta menjamin kepentingan nasional. Wawasan kebangsaan dimaknai sebagai pandangan yang mengandung kemampuan orang atau sekelompok orang dalam mengetahui keberadaan jati diri sebuah bangsa. Hal itu dilakukan dengan cara dalam memandang dirinya dan bertingkah laku sesuai falsafah dalam hidup bermasyarakat. Oleh karena itu, dalam kerangka Negara Kesatuan Republik Indonesia, visi kebangsaan adalah cara kita sebagai negara Indonesia memandang diri sendiri dan lingkungan untuk mencapai tujuan 
nasional yang meliputi perwujudan negara Indonesia yang berpedoman pada falsafah Pancasila dan Undang-Undang Dasar 1945.

\section{Makna Wawasan Kebangsaan}

Berbicara mengenai makna wawasan kebangsaan, tidak akan pernah terlepas dari sejarah bangsa itu sendiri. Wawasan kebangsaan yang dimiliki oleh bangsa Indonesia merupakan sebuah modal utama dalam membangun sebuah bangsa yang maju, yang mana hal itu merupakan dari warisan sejarah panjang perjuangan bangsa Indonesia di masa lalu. Salah satu cara memaknai wawasan kebangsaan secara praktek di lapangan adalah dengan mempopulerkan obyek-obyek bersejarah. Objek bersejarah ini merupakan sebuah jati di bangsa yang diidentifikasikan dengan identitas bangsa. Menurut Anis (2013:60) menyebutkan bahwasanya dengan dipopulerkannya obyek-obyek bersejarah ini kemudian ditafsirkan secara ideologis maka hal ini merupakan upaya dari negara dalam membangun warisan kultural, penghormatan atas para pahlawan, kesamaan norma yang sudah dibangun secara intens. Membangun identitas dan jati diri bangsa dalam sisi lain juga berarti upaya memperkuat ketahanan nasional, karena dengan demikian warga akan memiliki kesamaan visi tentang konstruksi kebangsaan. Konsep jati diri bangsa dapat disandingkan dengan identitas bangsa itu sendiri dimana salah satu unsur yang paling utama dalam jati diri bangsa adalah kesadaran sejarah. Kesadaran sejarah sangat penting diperlukan sebagai sebuah pembeda antara satu bangsa dengan bangsa lainnya (Anis, 2013:64).

Menurut Edi Sedywati dalam Anis (2013:64) menyatakan bahwa jati diri suatu bangsa dalam berbagai skala ditentukan oleh 2 (dua) hal, yang pertama adalah warisan budaya yang merupakan hasil dari perjuangan dan penciptaan di masa lampau, yang kedua adalah hasil daya cipta di masa sekarang yang dipacu dan didorong oleh berbagai macam tantangan dan kondisi nyata dan aktual yang terjadi di masa sekarang. Salah satu unsur penting dalam jati diri suatu bangsa adalah kesadaran sejarah secara subyketif. Dimana jati diri ini merupakan modal utama dalam sikap wawasan kebangsaan dalam membangun bangsa dan negara.

Selain mampu mengenali jati diri bangsa dengan mempopulerkan obyek-obyek bersejarah, makna wawasan kebangsaan adalah dengan mempelajari sejarah. Menurut Hasan dalam Anis (2014:192) menyatakan bahwa bila dihubungkan antara pendidikan sejarah dengan pendidikan karakter, maka dalam pendidikan sejarah terdapat berbagai pengembangan kemampuan berfikir kritis, kreatif, mengembangkan sikap kepahlawanan dan kepemimpinan, 
mengembangkan semangat kebangsaan, mengembangkan kepedulian sosial, mengembangkan kemampuan berkomunikasi dan mengembangkan kemampuan mencari, mengolah serta mampu mengkomunikasikan informasi. Nah, realita prakteknya di lapangan adalah dengan mempelajari nilai-nilai kepahlawanan yang harus dilestarikan dan disebarluaskan. Menurut Anis (2016:493) menyatakan bahwa kesadaran sejarah dalam pendidikan harus dipupuk dan dipelajari dengan seksama, karena sejarah merupakan kesadaran berbangsa dan bernegara. Hal itu dikarenakan sejarah merupakan modal bagi setiap warga negara dalam konsep wawasan kebangsaan. Jika tidak menghargai para pahlawan, bisa jadi mereka dianggap tidak Pancasilais dan buat apa mereka menjadi warga negara Indonesia.

Visi wawasan kebangsaan Indonesia berperan penting bagi bangsa Indonesia yang mana secara aktif mengantisipasi perkembangan lingkungan strategis dengan menjadi teladan bagi bangsa lain untuk menumbuhkan jati diri, kemandirian dan menghadapi tantangan eksternal tanpa konfrontasi dengan meyakinkan bangsa lain bahwa suatu bangsa merupakan aset yang dibutuhkan untuk mengembangkan nilai-nilai kemanusiaan. Salah satu makna wawasan kebangsaan dalam rangka mempertahankan Negara Kesatuan Republik Indonesia dari segala upaya rongrongan, diperlukan ketahanan sosial yang meliputi segala bidang ataupun sendi kehidupan salah satunya adalah pendidikan. Pendidikan merupakan faktor yang paling berpengaruh terhadap ketahanan di bidang sosial dan budaya. Melalui pendidikaan, masyarakat akan memperoleh kemampuan untuk menilai tradisi yang masih sesuai atau tidak terhadap perkembangan zaman. Pendidikan dimaknai sebagai upaya untuk mendewasakan manusia agar dapat mengembangkan potensinya serta berperan secara penuh dalam menumbuhkan kehidupan sosial sesuai tuntutan zaman. Salah satunya adalah pendidikan yang dilakukan oleh pesantren.

Dalam konteks kehidupan Pesantren, sebagai sebuah lembaga pendidikan Islam, maka wawasan kebangsaan lebih dimaknai dalam aspek kehidupan sosial. Mengenai bagaimana hidup harmonis dan rukun antar sesama santri, antar warga pesantren dengan warga di luar lingkungan pesantren. Kemudian bagaimana membangun relasi dan hubungan yang baik dengan warga sekitar. Sebagaimana kita tahu bahwasanya sebuah makna nilai mengenai wawasan kebangsaan haruslah di mulai dari sebuah konsep entitas yang kecil dalam hal ini yaitu pesantren 


\section{Wawasan Kebangsaan Santri Pada Aspek Sosial di Pesantren Intan Ilmu}

Pesantren Intan Ilmu merupakan sebuah lembaga pendidikan swasta yang beralamat di Jalan Gubernur Sarkawi, Sungai Bua Permai Desa Lok Rawa Kecamatan Mandastana Kabupaten Barito Kuala Provinsi Kalimantan Selatan. Pesantren Intan Ilmu mengusung sebuah konsep pendidikan untuk pesantren modern dengan mengemban sebuah visi yaitu, menjadi sebuah lembaga dakwah dan pendidikan Islam yang unggul di Indonesia serta amanah dengan mensuritauladani generasi terbaik umat Islam. Kemudian untuk misi dari Pesantren Intan Ilmu adalah:

1. Menyelenggarakan lembaga pendidikan Islam yang unggul, amanah, profesional dan mensuritauladani generasi terbaik umat Islam;

2. Melaksanakan dakwah Islam yang berorientasi pada generasi terbaik umat Islam

3. Menciptakan kultur pesantren yang tetap menjaga kearifan lokal wilayah Kalimantan Selatan;

4. Melaksanakan pengabdian kepada masyarakat sebagai wujud implementasi ilmu pengetahuan yang berlandaskan nilai-nilai Islam untuk kesejahteraan umat;

5. Menyelenggarakan sebuah kegiatan pembinaan ke-Islaman baik secara khusus, maupun terintegrasi dengan pembekalan konten bidang ilmu.

Pesantren Intan Ilmu menerapkan pendidikan santri dengan sistem mondok atau asrama yang dimulai dari jenjang SMP sampai dengan jenjang SMA. Pesantren Intan Ilmu memilih jalur pendidikan belajar formal di bawah naungan Kementrian Pendidikan dan Kebudayaan Nasional dengan Izin Pendirian Nomor: 503/420/002/DPMPTSP-BTL/2019 tanggal 20 November 2019 dan Izin Operasional Sekolah SMP Intan Ilmu Nomor: 423.5/117/Pembinaan SMP-Disdik/2019 Tanggal 26 November 2019.

Pentingnya santri di Pesantren Intan Ilmu dalam memahami arti dari wawasan kebangsaan adalah sebagai bentuk kontrol terhadap ilmu agama yang didapatkan di pesantren agar dipergunakan untuk menggapai masa depan bangsa yang religius namun tetap cinta terhadap tanah airnya. Untuk itu makna penanaman sikap wawasan kebangsaan bukan hanya sebatas teori yang hanya diajarkan dalam mata pelajaran Pendidikan Kewarganegaraan, IPS dan juga Seni Budaya di Pesantren Intan Ilmu, namun juga dengan melaksanakan sebuah praktek langsung di lapangan. Pesantren Intan Ilmu memiliki hubungan yang erat dengan warga desa lok rawa mandastana di sekitarnya. 
Membicarakan wawasan kebangsaan merupakan sebuah arti yang luas dalam persepektif pengertiannya. Wawasan kebangsaan bisa diartikan dalam konsep sebuah nilai, sikap ataupun cara pandang. Nilai pandang dari konsep wawasan kebangsaan yang terwujud di dalam perwujudan persatuan bangsa salah satunya adalah nilai kesetiakawanan sosial. Kehidupan para santrri di asrama selama 24 jam, mengharuskan agar para santri bisa beradaptasi dengan lingkungan yang baru. Hal itu nantinya akan menumbuhkan sikap rasa kesetiakawanan sosial dalam kehidupan di lingkungan Pesantren Intan Ilmu.

Pengetahuan santri terhadap wawasan kebangsaan di Pesantren Intan Ilmu tidak jauh berbeda dengan pondok pesantren pada umumnya, ada kegiatan mengaji, berdiskusi dan kegiatan sosial. Walaupun umur Pesantren Intan Ilmu masih sangat muda, namun dalam konteks pelaksanaan selama berdirinya pesantren di sekitar warga desa lok rawa, telah memberikan kaidah nilai-nilai wawasan kebangsaan terutama dalam aspek kesejahteraan sosial bagi warga sekitar. Sebelumnya, daerah lok rawa ini merupakan daerah hutan gambut yang hanya dijadikan jalan pintas bagi masyarakat dari daerah Kalimantan tengah menuju kearah Banjarbaru dan sekitarnya. Kegiatan ekonomi warga sekitar hampir tidak ada disekitarnya, dikarenakan daerahnya yang sepi dan mayoritas warga yang kebanyakan petani. Namun setelah Pesantren Intan Ilmu berdiri, kini menjadi sebuah wadah pendidikan di daerah lok rawa mandastana Barito Kuala, banyak warga sekitar yang merasa sangat senang dengan keberadaan Pesantren Intan Ilmu. Selain dapat membantu warga dengan berbagai kegiatan sosialnya, bahkan ada beberapa warga yang dipekerjakan sebagai karyawan di Pesantren Intan Ilmu.

Pengimplementasian wawasan kebangsaan dalam kehidupan santri di Pesantren Intan ilmu yang merupakan jiwa, cita-cita atau falsafah hidup tidak lahir dengan sendirinya. Wawasan kebangsaan sejatinya adalah proses konstruksi dari realita sosial atau politik. Wawasan kebangsaan mengandung sebuah perwujudan jati diri dalam mewujudkan pengembangan sikap bangsa yang yakin akan nilai budaya tersebut. Yang mana budaya tersebut dilahirkan dan berkembang sebagai wujud kepribadiannya. Demi melestarikan budaya bangsa, maka wawasan kebangsaan mempunyai arti penting sebagai benteng kokoh untuk mempertahankan kultur bangsa Indonesia agar tidak tergerus ke arus globalisasi saat ini. Selain itu juga, kebudayaan merupakan dasar hidup bangsa dalam kehidupan bermasyarakat bangsa dan negara.

Wawasan kebangsaan bagi santri sebagai pedoman hidup dalam kaidah berbangsa dan bernegara. Mereka menganggap wawasan kebangsaan adalah hal yang begitu mudah dipahami, 
namun pada pemahamannya menurut pengetahuan mereka begitu luas. Menurut para santri terkait pengetahuan mengenai wawasan kebangsaan di Pesantren Intan Ilmu. Menurut santri kelas 7 yang bernama Syafiq Abimanyu dalam memahami makna wawasan kebangsaan bahwasanya:

Wawasan kebangsaan merupakan cara seseorang ataupun kelompok memandang jati dirinya dalam pandangan kewajibannya sebagai warga negara dengan menerapkan aturan, etika dan kewajiban sebagai warga negara untuk mewujudkan bangsa dan negara yang beretika, beradab dan maju.

Pendapat lain menurut santri kelas 7 yang bernama Rifki Andika Havid dalam memahami makna wawasan kebangsaan:

Wawasan kebangsaan merupakan sudut pandang seseorang atau sekelompok orang untuk memahami keberadaan jati diri sebagai suatu bangsa dan juga wawasan kebangsaan merupakan sikap warga negara terhadap negaranya dan memiliki rasa cinta tanah air.

Sementara itu menurut santri kelas 7 yang lain yang bernama Muhammad Rizqi Naufal Aziz dalam memahami wawasan kebangsaan:

Wawasan kebangsaan merupakan pengetahuan sikap suatu negara terhadap negaranya yang sesuai dengan nilai-nilai Pancasila dan aturan yang ada.

Dari beberapa pendapat santri mengenai implementasi wawasan kebangsaan, adalah dengan penerapan dimulai dari hal-hal yang bersifat kecil. Seperti menghargai antar sesama santri, menghargai para guru dan ustadz pengajar, bersikap ramah kepada warga sekitar, saling tolong menolong dalam hal kebaikan.

Kemudian terkait bagaiman pengimplementasiannya dalam aspek kehidupan sosial di Pesantren. Pendapat santri kelas 7 yang bernama M. Cavan Rizal Aveco mengenai implementasi wawasan kebangsaan di lingkungan Pesantren mengatakan bahwasanya:

Cara menerapkan sikap dan nilai wawasan kebangsaan pada kehidupan sosial di lingkungan Pesantren Intan Ilmu adalah dengan kita saling membantu saat di pesantren, namun tidak hanya di Pesantren saja, tapi juga saling membantu di lingkungan masyarakat. Contohnya membantu teman yang lain saat teman mengalami kesusahan, 
misalnya membantu teman saat membersihkan kelas. Lalu kita juga harus saling menghargai teman yangberbeda suku, berbeda bahasa dan warna kulit, semuanya harus dihargai dan tidak boleh mencela.

Dengan cara hal yang demikian, kedepannya akan menumbuhkan sikap dari kesetiakawanan sosial yang mana hal ini merupakan perwujudan dari nilai wawasan kebangsaan itu sendiri. Pengimplementasian lainnya adalah dengan wujud penanaman sikap wawasan kebangsaan bukan hanya sebatas teori yang hanya diajarkan dalam mata pelajaran Pendidikan Kewarganegaraan, IPS dan juga Seni Budaya di Pesantren Intan Ilmu, namun juga dengan melaksanakan sebuah praktek langsung di lapangan. Pesantren Intan Ilmu memiliki hubungan yang erat dengan warga desa lok rawa mandastana di sekitarnya. Seringnya acara kegiatan yang bersifat sosial yang dilakukan oleh Pesantren setiap tahunnya seperti Penyaluran Zakat Maal, Penyaluran hewan qurban, sunatan massal, dan kegiatan berbagi sembako di tengah masa pandemi Covid-19. Kegiatan-kegiatan sosial tersebut merupakan wujud kongkret sikap wawasan kebangsaan Pesantren Intan Ilmu dalam membina hubungan yang baik dalam kehidupan bermasyarakat berbangsa dan bernegara. Pentingnya santri di Pesantren Intan Ilmu dalam memahami arti dari wawasan kebangsaan adalah sebagai bentuk kontrol terhadap ilmu agama yang didapatkan di pondok pesantren agar dipergunakan untuk membangun masa depan bangsa yang religius namun tetap cinta terhadap tanah airnya.

Kemudian, terkait mengenai kendala para santri dalam menerapkan kaidah sikap dan nilai wawasan kebangsaan pada lingkungan Pesantren Intan Ilmu diantaranya menurut santri kelas 7 yang bernama Syafiq Abimanyu mengatakan bahwasanya

Kendala yang pertama yaitu menurut saya adalah niat, jika seseorang melakukan kewajiban bernegara dengan tidak mengikhlaskan niat, maka serasa ada yang ganjil dan kurang di dalam hasil. Bahkan mungkin hasilnya kurang dari 100\%. Maksudnya adalah hasil tersebut tidak akan sempurna bahkan bisa dibilang jauh dari apa yang diharapkan dan diwujudkan. Kemudian kedua adalah kurang fokus. Kurang fokus juga bisa menjadi kendala walaupun niatnya sudah mantap, namun bisa jadi pada saat penerapannya dia malah tidak fokus. Lalu yang terakhir adalah adab. Adab diperlukan dalam menerapkan sikap dan nilai wawasan kebangsaan seperti apabila adab tidak dijaga pada saat kegiatan belajara mengajar, maka ilmu yang didapat akan hilang. 
Pendapat lain dari santri Muhammad Rizqi Naufal Aziz salah satu santri kelas 7 juga menambahkan mengenai kendala dalam penerapan sikap dan nilai mengenai wawasan kebangsaan di Pesantren Intan Ilmu adalah

Banyak santri yang kadang tidak mematuhi peraturan dan sering terjadi perdebatan yang bisa mengarah ke arah perkelahian.

Kemudian Menurut santri kelas 7 yang bernama Thabit Al Azizi, mengatakan bahwasanya: Kendalanya adalah emosi dan sikap yang kurang baik dalam penerapan sikap wawasan kebangsaan.

Lalu juga Cavan Rizal Aveco, santri kelas 7 juga menambahkan terkait kendala dalam penerapan sikap dan nilai mengenai wawasan kebangsaan di Pesantren Intan Ilmu mengatakan bahwa:

Terkadang suatu proses itu tidak seperti jalan tol. Terkadang masih saja ada teman yang sombong, sehingga enggan menolong, terkadang juga ada teman yang masih belum bisa saling menghargai, kadang bisa juga ada yang mengejek dan membully, namun Alhamdulillah di Pesantren tidak ada pembullyan.

Nilai-nilai yang terkandung dalam wawasan kebangsaan bagi santri adalah sebagai wahana kehidupan yang religius, yang diwujudkan dengan cara beribadah dengan keyakinan bahwasanya hanya Allah Subhanahu Wata'ala yang berhak disembah dan diibadahi yang tertuang dalam sila ke-1. Memang bagi para santri di Pesantren Intan Ilmu, kaidah konsep nilai wawasan kebangsaan dalam memandang dan mengimplementasikannya berbeda-beda, tergantung individu dan proses yang dialami mereka masing-masing. Namun hal itu tidak menyurutkan semangat mereka untuk mendalami dan mengkaji secara lebih mendalam mengenai pentingnya wawasan kebangsaan bagi diri mereka sendiri. Wawasan kebangsaan membentuk manusia Indonesia seutuhnya dan masyarakat sebagai objek dan subjek usaha pembangunan nasional menuju masyarakat yang berlandaskan Pancasila. Paham kebangsaan dimaknai para santri bahwa paham tidak hanya dimengerti. Namun juga harus diimplementasikan ke dalam kehidupan nyata. Paham kebangsaan merupakan pemahaman rakyat dan masyarakat terhadap 
bangsa dan negara yang berkembang dari waktu ke waktu serta berbeda dalam satu lingkungan masyarakat dengan lingkungannya.

\section{SIMPULAN DAN SARAN}

Wawasan kebangsaan merupakan suatu cara pandang negara dalam mewujudkan cita-cita bangsa. Wawasan kebangsaan merupakan bagian dari nilai-nilai Pancasila, UUD 1945 dan Bhineka Tunggal Ika. Kemudian nilai-nilai tersebut diimplementasikan kedalam segala aspek kehidupan masyarakat diantaranya aspek kehidupan sosial. Ada beberapa cara santri dalam mengimplementasikan sikap dan cara wawasan kebangsaan di lingkungan Pesantren Intan Ilmu, yaitu dengan memulai dari hal-hal yang bersifat kecil, misalkan dengan menghargai antar sesama santri, menghargai para guru dan ustadz pengajar, bersikap ramah kepada warga sekitar, saling tolong menolong dalam hal kebaikan. Agar nantinya hal-hal yang dilakukan yang bersifat kecil tersebut menjadi sebuah kebiasaan dan akhirnya tertanam dalam kepribadian dan membentuk sebuah karakter bangsa yang memiliki sikap akhlak budi pekerti yang luhur dan berakar agama berupa iman yang kuat serta dibalut dengan ilmu pengetahuan.

Selain itu juga, agenda-agenda kegiatan sosial di Pesantren Intan Ilmu yang pengimplementasiannya adalah dengan wujud nyata berupa penanaman sikap wawasan kebangsaan yang mana hal itu bukan hanya sebatas teori yang hanya diajarkan dalam mata pelajaran Pendidikan Kewarganegaraan, IPS dan juga Seni Budaya di Pesantren Intan Ilmu, namun juga dengan melaksanakan sebuah praktek langsung di lapangan. Seringnya acara kegiatan yang bersifat sosial yang dilakukan oleh Pesantren setiap tahunnya seperti Penyaluran Zakat Maal, Penyaluran hewan qurban, sunatan massal, dan kegiatan berbagi sembako di tengah masa pandemi Covid-19. Kegiatan-kegiatan sosial tersebut merupakan wujud kongkret sikap wawasan kebangsaan Pesantren Intan Ilmu dalam membina hubungan yang baik dalam kehidupan bermasyarakat berbangsa dan bernegara

Sikap dan nilai ini bagi para santri sangatlah perlu digunakan untuk menjadi bagian dari pergerakan kemajuan bangsa dan negara. Selain itu juga mereka memiliki peran penting karena dinilai dari kemampuan, semangat dan pengetahuan yang lebih unggul dibandingkan masyarakat pada umumnya, apalagi jika mereka dibekali dengan ilmu agama serta memiliki akhlak dan budi pekerti yang bagus. Tentunya hal ini akan menimbulkan sebuah perubahan yang besar dalam mewujudkan tujuan bangsa dan negara. Pentingnya santri di Pesantren Intan Ilmu dalam 
memahami arti dari wawasan kebangsaan adalah sebagai bentuk kontrol terhadap ilmu agama yang didapatkan di pesantren agar dipergunakan untuk membangun masa depan bangsa yang religius namun tetap cinta terhadap tanah airnya.

\section{DAFTAR PUSTAKA:}

Anis, M. Z. A. (2016). Sejarah, Kesadaran Sejarah dan Pupusnya Identitas Nasional.

Chandra, P. (2020). Peran Pondok Pesantren dalam Membentuk Karakter Bangsa Santri di Era Disrupsi. Belajea; Jurnal Pendidikan Islam, 5(2), 243-262.

Ernas, S., \& Siregar, F. M. (2010). Dampak Keterlibatan Pesantren dalam Politik: Studi Kasus Pesantren di Yogyakarta. Kontekstualita: Jurnal Penelitian Sosial Keagamaan, 25(2), 37094.

Fauzi, A. (2017). WAWASAN KEBANGSAAN SISWA MTs DAN SMP.

Jazuli, A. (2017). KONTRUKSI SANTRI TENTANG WAWASAN KEBANGSAAN DI PONDOK PESANTREN BURENG KECAMATAN WONOKROMO KOTA SURABAYA. Kajian Moral dan Kewarganegaraan, 5(01).

Negara, L. A. (2014). Wawasan Kebangsaan Dalam Kerangka Negara Kesatuan Republik Indonesia. Jakarta, LAN.

Raco, J. (2018). Metode penelitian kualitatif: jenis, karakteristik dan keunggulannya.

Sakti, M. B., Suntoro, I., \& Nurmalisa, Y. (2018). Peranan Pesantren Dalam Menumbuhkan Wawasan Kebangsaan Kepada Santri.

Silfiyasari, M., \& Zhafi, A. A. (2020). Peran Pesantren dalam Pendidikan Karakter di Era Globalisasi. Jurnal Pendidikan Islam Indonesia, 5(1), 127-135.

Wiranata, R. R. S. (2019). Tantangan, Prospek dan Peran Pesantren Dalam Pendidikan Karakter di Era Revolusi Industri 4.0. Journal Al-Manar, 8(1), 61-92.

Zaenal Arifin Anis, M. Obyek Sejarah, Jatidiri Bangsa dan Ketahanan Nasional.

Zaenal Arifin Anis, M. Pendidikan Sejarah Berbasis Pendidikan Karakter. 